\title{
Removal of Some Toxic Ions from Seawater and Wastewater by Sorption onto Natural, Synthetic Hydroxyapatite and Alginate-Hydroxyapatite Composite Nanoparticles: A Comparative Study
}

\author{
Mohamed A. Shreadah1", Osama E. M. Rizk¹, Mohamed A. Aly-Eldeen', Amal R. Rashad², \\ Mohamed E. Mahmoud ${ }^{2}$ \\ ${ }^{1}$ National Institute of Oceanography and Fisheries, Alexandria Branch, Alexandria, Egypt \\ ${ }^{2}$ Chemistry Department, Faculty of Science, Alexandria University, Alexandria, Egypt \\ Email: *niof.shreadah@gmail.com
}

How to cite this paper: Shreadah, M.A., Rizk, O.E.M., Aly-Eldeen, M.A., Rashad, A.R. and Mahmoud, M.E. (2019) Removal of Some Toxic Ions from Seawater and Wastewater by Sorption onto Natural, Synthetic Hydroxyapatite and Alginate-Hydroxyapatite Composite Nanoparticles: A Comparative Study. Journal of Environmental Protection, 10, 1155-1173.

https://doi.org/10.4236/jep.2019.109069

Received: August 2, 2019

Accepted: September 9, 2019

Published: September 12, 2019

Copyright $\odot 2019$ by author(s) and Scientific Research Publishing Inc. This work is licensed under the Creative Commons Attribution International License (CC BY 4.0).

http://creativecommons.org/licenses/by/4.0/

\begin{abstract}
The main objective of this paper is to study the removal of Cadmium(II), Lead(II), Chromium(VI), and Mercury(II) ions by sorption onto different natural and synthetic nanoparticles. Special attention has been given to the application of fish bone in nanoform as a useful, inexpensive and eco-friendly alternative material. A comparison between natural hydroxyapatite (fish bone), synthetic hydroxyapatite nanoparticles (HAP) and alginate-hydroxyapatite composite (Alg/Hap) to assess their removal efficiencies to remediate the selected heavy metals has been done. Surface characterization by using different techniques has also been performed to understand the influence of surface characteristics of the adsorbent materials in the removal process. Different parameters $(\mathrm{pH}$, contact time, mass dose and metal ion concentration) have been examined to identify the optimum conditions for remediation of different metals from polluted water. The potential applications of the biosorbents for removal and sorption of these metal ions from seawater and wastewater samples were also investigated and evaluated.
\end{abstract}

\section{Keywords}

Cadmium(II), Lead(II), Chromium(VI), Mercury(II), Ions Removal, Nano-Biosorbent, Seawater and Wastewater

\section{Introduction}

Environmental pollution, in general, is a major hazard facing the world today 
and there is an increasing awareness about protection of the marine environment which became one of the major challenges facing the world [1]-[9]. Pollution due to the discharge of heavy metals in the marine environment of Egypt has received recently considerable concern due to their toxicity, abundance and persistence in the environment [10]-[19].

Common removal technologies of heavy metals are membrane separation, ion exchange, electrodeposition, and chemical precipitation. These methods proved to be costly and inept, especially in removing trace amounts of heavy metals. Another disadvantage is the production of sludge or mud, which requires proper disposal and confinement. On the other hand, adsorption effectively removes contaminants from wastewater with high solute loadings and even at dilute concentrations $(<100 \mathrm{mg} / \mathrm{l})$ [20] [21] [22] [23].

A wide range of biomaterials available in nature has been employed as biosorbents for the desired pollutant removal. Various forms of fish bones have been utilized including but not limited to a) cobalt removal by animal bones; b) lead removal by fish bone waste hydroxyapatite powder; c) immobilization of lead with nanocrystalline carbonated apatite present in fish bone; d) anchoring hazardous metal ions using modified fishbone; e) lead removal using unmodified fishbone; f) lead removal using waste fish bone via ion exchange; and g) desorption of lead adsorbed by fish bone. Thus, fish bones have become an attractive, cheap and abundant waste for in-situ lead stabilization from contaminated waters [24] [25] [26] [27] [28].

In this study, special attention has been given to the application of fish bones in a nanoform to remove Cadmium(II), Lead(II), Chromium(VI), and Mercury(II) ions from contaminated waters. A comparison between natural hydroxyapatite (fish bones), synthetic hydroxyapatite nanoparticles (HAP) and alginate-hydroxyapatite composite (Alg/Hap) was carried out to assess their removal efficiencies to remediate the selected heavy metals.

\section{Materials and Methods}

\subsection{Equipment}

A scanning electron microscope (SEM) was used equipped with FEI Quanta 250 Orbit to monitor and characterize the surface morphology of all nanobiosorbents under study. A JEOL-JEM2100 (Japan) high resolution transmission electron microscope (HR-TEM) was applied to determine the particle size diameters and the inner surface morphology of all nanobiosorbents. A FT-IR spectra was recorded on a Shimazdu Prestige-21 FTIR between 400 and $4000 \mathrm{~cm}^{-1}$. A Powder X-ray diffractometer (XPERT-PRO-Analytical-Netherland) was used to evaluate the surface structure of the prepared nanobiosorbent by using Ni-filtered $\mathrm{CuKa}$ radiation at $45 \mathrm{KV}$ in the range of $10-80$ (2-theta) and by using $\mathrm{K}=0.9$ as Scherrer constant. The crystalline size is calculated by using Scherrer Equation (1):

$$
D=\frac{0.9 \lambda}{\beta \cos \theta}
$$


where $\lambda$ is the wavelength of the $\mathrm{X}$-ray radiation and $\beta$ is the full width at half maximum of the peaks at a diffracting angle $\theta$.

Thermogravimetric analyses (TGA) were carried out in a nitrogen atmosphere using Perkin-Elmer TGA7 Thermo balance. The selected operating conditions are a temperature heating range $=20^{\circ} \mathrm{C}-600^{\circ} \mathrm{C}$, a heating rate $=10^{\circ} \mathrm{C} \cdot \mathrm{min}^{-1}$, a flow rate $=20 \mathrm{~mL} \cdot \mathrm{min}^{-1}$ pure nitrogen atmosphere and the sample mass was taken in the range of $5.0-6.0 \mathrm{mg}$.

Determination of metals concentrations was carried out by using an Agilent atomic absorption spectrophotometer (240 AA Spectrometer). The flame unit was used together with an auto-sampler (Agilent SPS3 Autosampler) for automated flame operation at the appropriate wavelength for each metal.

\subsection{Preparation of Different Biosorbents}

\subsubsection{Preparation of Nanopowders Hydroxyapatitefrom Fish Scales}

Bones of Tilapia nilotica fish were collected from a local market, and then washed with hot distilled water for several times to remove any organic compounds. Additional washing with $0.1 \mathrm{M} \mathrm{HCl}$ followed by distilled water for several times. The remaining proteins of fish bones were then treated with $5 \% \mathrm{NaOH}$, heated and stirred at $70^{\circ} \mathrm{C}$ for $5 \mathrm{hr}$. Next, the washed fish bones were dried in an oven at $80^{\circ} \mathrm{C}$ and then ground by ball mill and sieved for the desired size range. The HAP nanopowder was then washed thoroughly with deionized water until the washing solution became neutral and then dried at $80^{\circ} \mathrm{C}$ [29].

\subsubsection{Preparation of Nanohydroxyapatite (HAP)}

Hydroxyapatite compounds were prepared by the solution-precipitation method using calcium nitrate $\left(\mathrm{Ca}\left(\mathrm{NO}_{3}\right)_{2} \cdot 4 \mathrm{H}_{2} \mathrm{O}\right)$ and diammonium hydrogen phosphate $\left(\left(\mathrm{NH}_{4}\right)_{2} \mathrm{HPO}_{4}\right)$, in addition to ammonia solution for $\mathrm{pH}$ adjustment. A suspension of $\mathrm{Ca}\left(\mathrm{NO}_{3}\right)_{2} \cdot 4 \mathrm{H}_{2} \mathrm{O}(23.61 \mathrm{~g}$ in $350 \mathrm{ml}$ distilled water) was vigorously stirred at $25^{\circ} \mathrm{C}$. A solution of $\left(\mathrm{NH}_{4}\right)_{2} \mathrm{HPO}_{4}(7.92 \mathrm{~g}$ in $250 \mathrm{ml}$ distilled water) was slowly added dropwise to the $\mathrm{Ca}\left(\mathrm{NO}_{3}\right)_{2} \cdot 4 \mathrm{H}_{2} \mathrm{O}$ solution. In all experiments pHs were kept at 11 by ammonia solution. This can be explained by the following reaction:

$10 \mathrm{Ca}\left(\mathrm{NO}_{3}\right)_{2} \cdot 4 \mathrm{H}_{2} \mathrm{O}+6\left(\mathrm{NH}_{4}\right)_{2} \mathrm{HPO}_{4}+8 \mathrm{NH}_{4} \mathrm{OH} \rightarrow \mathrm{Ca}_{10}\left(\mathrm{PO}_{4}\right)_{6}(\mathrm{OH})_{2}+20 \mathrm{NH}_{4} \mathrm{NO}_{3}+20 \mathrm{H}_{2} \mathrm{O}$

Precipitated HAP was removed from the solution by centrifugation at 3000 $\mathrm{rpm}$. The resulting powder was dried at $80^{\circ} \mathrm{C}$ [30].

\subsubsection{Preparation of Alginate/Hydroxyapatite Composite (Alg/Hap)}

The alginate/hydroxyapatite composite was prepared by dissolving $1.5 \mathrm{~g}$ of sodium alginate (SA) in $36 \mathrm{~mL}$ of distilled water at $40^{\circ} \mathrm{C}$ and $1000 \mathrm{rpm}$. After the complete dissolution of SA, $0.6 \mathrm{~g}$ of diammonium hydrogen phosphate $\left(\left(\mathrm{NH}_{4}\right)_{2} \mathrm{HPO}_{4}\right)$ was dissolved in $12.5 \mathrm{~mL}$ of distilled water. Then it was added slowly into the SA aqueous solution with stirring the mixture for $1 \mathrm{hr}$ to ensure the homogeneity of the system. Subsequently, the aqueous solution containing $\mathrm{SA}$ and $\left(\mathrm{NH}_{4}\right)_{2} \mathrm{HPO}_{4}$ was added dropwise into $6 \% \mathrm{Ca}\left(\mathrm{NO}_{3}\right)_{2} \cdot 4 \mathrm{H}_{2} \mathrm{O}(30 \mathrm{~g}$ in 500 $\mathrm{mL}$ distilled water) aqueous solution at $30^{\circ} \mathrm{C}$ with moderate stirring $(50 \mathrm{rpm})$ 
through a $1.2 \mathrm{~mm}$ inner diameter needle, using a hypodermic syringe. The $\mathrm{pH}$ of the system was maintained in the range $10-10.5$ using ammonia solution. The milky white composite beads were formed immediately (Figure 1) and further cross linked for $16 \mathrm{hr}$. After that, the Alg/Hap composite beads were filtered and rinsed three times with distilled water to remove the excess $\mathrm{Ca}(\mathrm{II})$ and other impurities on the surface of the beads. It then dried at $40^{\circ} \mathrm{C}$ overnight [31].

\subsection{Biosorption Studies}

All batch sorption experiments were carried out at room temperature $\left(25^{\circ} \mathrm{C} \pm\right.$ $1^{\circ} \mathrm{C}$ ). Each experiment was performed by mixing a $1.0 \mathrm{ml}$ of $0.1 \mathrm{~mol} \cdot \mathrm{L}^{-1}$ metal ion solution in $50 \mathrm{~mL}$ pyrex bottle with $30 \mathrm{mg}$ of the dry biosorbent and the $\mathrm{pH}$ was adjusted by adding $9.0 \mathrm{ml}$ of buffer solution ( $\mathrm{pH}$ 1-7). Then shaking by using a shaker for $30 \mathrm{~min}$, filtered and washed with $50 \mathrm{ml}$ distilled water. The residual metal ions in the filtrate were determined by EDTA titrations and each experiment was repeated three times.

To estimate the effect of mass of the novel cellulose sorbent, similar batch experiments were carried out by using different biosorbents masses of 5.0, 10.0, 15.0, 20.0, 30.0, 40.0 and $50.0 \mathrm{mg}$.

The effect of the reaction time was investigated for different shaking time of 5 , $10,15,20,30,40$ and $50 \mathrm{~min}$ ) at the optimum buffering condition of each metal.

Sorption equilibrium and isotherm studies were evaluated by varying the initial metal ion concentration from 0.025 to $1.0 \mathrm{M}$.

Removal and biosorption capacity of $\mathrm{Cd}(\mathrm{II})$ and $\mathrm{Pb}(\mathrm{II})$ ions were investigated in presence of other competing ions of molar concentration. The examined solutions were prepared by mixing a $1.0 \mathrm{~mL}$ of $0.1 \mathrm{~mol} \cdot \mathrm{L}^{-1}$ solution of the metal under study with a $100 \mathrm{mg}$ of an interfering ion $(\mathrm{Na}(\mathrm{I}), \mathrm{K}(\mathrm{I}), \mathrm{Ca}(\mathrm{II})$ and $\mathrm{Mg}(\mathrm{II})$ ) individually. The residual metal content was determined by atomic absorption spectrometer.

Biosorption capacity of metal ions $\left(\mu \mathrm{mol} \cdot \mathrm{g}^{-1}\right)$ was calculated from Equation (2).

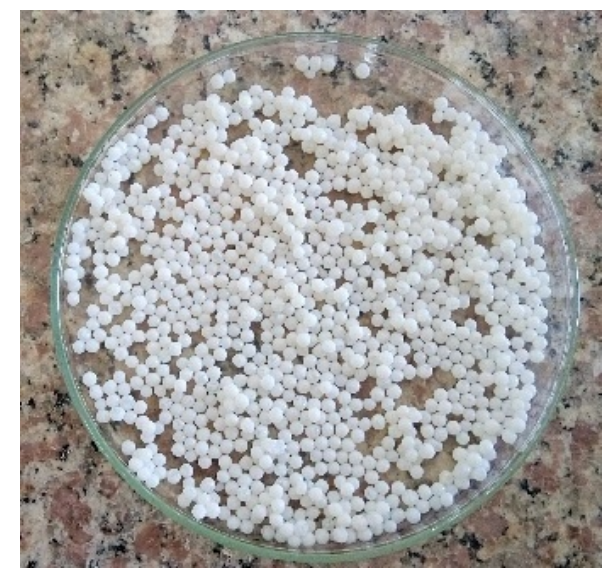

Figure 1. Alginate/hydroxyapatite milky white composite beads. 


$$
q=\frac{\left(C_{o}-C\right) V}{m} \times 10^{3}
$$

where, $C_{o}$ and $C\left(\mathrm{~mol} \cdot \mathrm{L}^{-1}\right)$ are the initial and residual metal ion concentration respectively, $V(\mathrm{~L})$ is the aqueous volume of the sorption reaction, $m(\mathrm{~g})$ is the mass of dry biosorbent and $q\left(\mu \mathrm{mol} \cdot \mathrm{g}^{-1}\right)$ is the biosorption metal capacity that represents the amount of metal ion $(\mu \mathrm{mol})$ adsorbed per gram of dry biosorbent.

\subsection{Removal of $\mathrm{Cd}(\mathrm{II}), \mathrm{Pb}(\mathrm{II}), \mathrm{Cr}(\mathrm{VI})$, and $\mathrm{Hg}(\mathrm{II})$ Ions from Seawater and Wastewater Samples}

Seawater samples were collected from the Eastern harbor and El-Max bay at the Egyptian Mediterranean Coast in addition to a wastewater sample collected from Al-Qala drain at Lake Mariout. Water samples were studied and evaluated to examine the efficiency of various biosorbents for removal and selective extraction of $\mathrm{Cd}, \mathrm{Pb}, \mathrm{Cr}(\mathrm{VI})$, and $\mathrm{Hg}(\mathrm{II})$ ions. Each sample was first analyzed to identify the concentrations of each metal ion and then spiked with $\mathrm{Cd}, \mathrm{Pb}, \mathrm{Cr}(\mathrm{VI})$, and $\mathrm{Hg}$ (II) ions. One liter of each sample was passed triplicate times throughout a multi-stages micro-column packed with $100 \mathrm{mg}$ of the dry biosorbent under constant flow rate $\left(10 \mathrm{~mL} \cdot \mathrm{min}^{-1}\right)$. The effluent was collected and the concentrations of different metals were analyzed by the atomic absorption spectrometer. The percentage of metal extraction was then calculated using Equation (3).

$$
\%=\frac{\left(C_{o}-C\right)}{C_{o}} \times 100
$$

where, $C_{o}$ and $C\left(\mathrm{~mol} \cdot \mathrm{L}^{-1}\right)$ are the initial and residual metal ion concentration respectively [32].

\section{Results and Discussion}

\subsection{Surface Morphology and Characterization}

The SEM micrographs of the different biosorbents before the adsorption process are shown in Figures 2(a)-(c) for natural fish bones (F.B), synthetic hydroxyapatite (HAP)and (C) alginate hydroxyapatite composite (Alg/Hap).to adsorb on its surface. The pores with its clear openings facilitate the accessibility of metal ions adsorption into the internal part of the biosorbent [33].

HR-TEM micrographs of the different biosorbents are shown in Figures 3(a)-(c) for natural fish bones (F.B), synthetic hydroxyapatite (HAP) and alginate hydroxyapatite composite (Alg/Hap), respectively. Powders were dispersed in ethanol under ultra-sonication. Then a drop of the solution was placed onto a $\mathrm{Cu}$ grid coated with a thin holey carbon film. The samples were measured at 200 $\mathrm{kV}$. It is noticed that there are several numbers of heterogeneous porous layer which may provide a good possibility for the adsorption of the examined metals.

Fourier transform infrared (FT-IR) spectroscopy was employed to characterize the different functional groups of (HAP) powder obtained from fish bones, synthetic hydroxyapatite (HAP) and alginate hydroxyapatite composite 


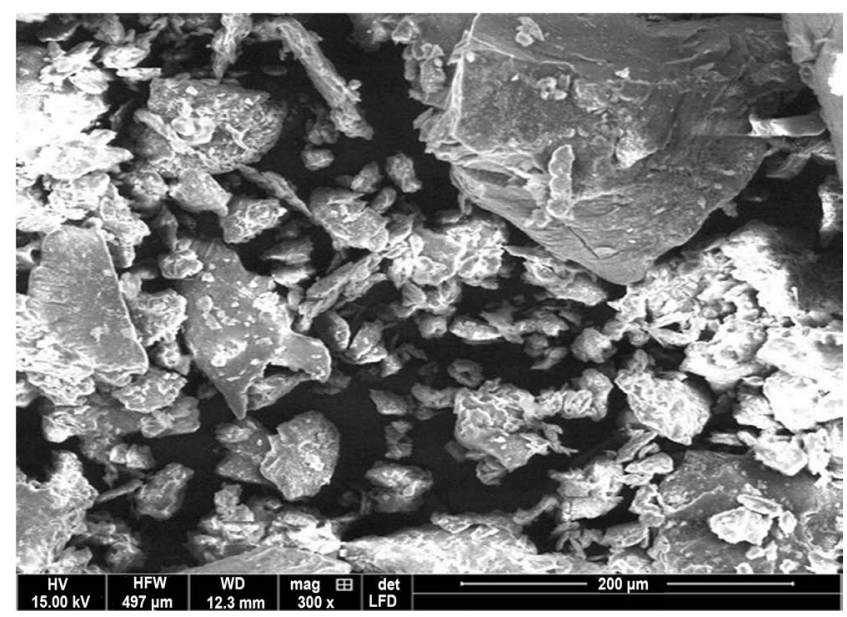

(a)

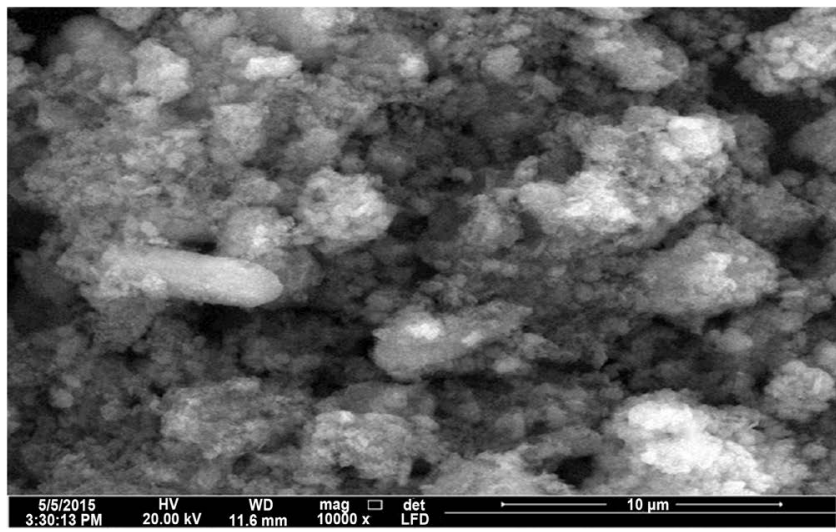

(b)

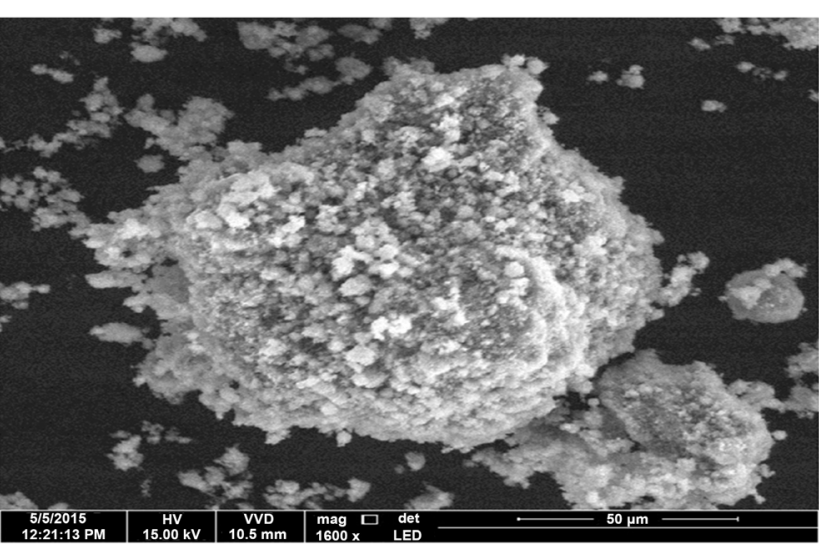

(c)

Figure 2. SEM images of (a) fish bones (F.B), (b) synthetic hydroxyapatite (HAP) and (c) alginate hydroxyapatite composite.

(Alg/Hap) (Figures 4(a)-(c)). All Peaks assignments are listed in Table 1. Stretching $\left(3430 \mathrm{~cm}^{-1}\right)$ and vibration $\left(634 \mathrm{~cm}^{-1}\right)$ peaks illustrate the characteristic bands of the HAP structure. The broad band at $3430 \mathrm{~cm}^{-1}$ corresponds to stretching mode of hydroxyl (-OH) groups. A broad band at $\left(2800-3400 \mathrm{~cm}^{-1}\right)$ was mainly due to stretching vibrations of $-\mathrm{OH}$ groups of adsorbed water. The band at $\left(1658 \mathrm{~cm}^{-1}\right)$ is attributed to the $v_{2}$ bending mode of the $\mathrm{H}_{2} \mathrm{O}$ molecule. The group of bands between $\left(1410-1550 \mathrm{~cm}^{-1}\right)$ were assigned to carbonate $\left(\mathrm{CO}_{3}\right)^{2-}$. The intense bands in the range of $\left(950-1100 \mathrm{~cm}^{-1}\right)$ corresponding to P-O stretching vibration mode (asymmetric or $v_{3}$ ) of the phosphate groups. The sharp peaks at $\left(604-560 \mathrm{~cm}^{-1}\right)$ correspond to the (O-P-O) bending mode [29].

XRD patterns of HAP $\left(\mathrm{Ca}_{10}\left(\mathrm{PO}_{4}\right)_{6}(\mathrm{OH})_{2}\right)$ powder obtained from fish bones, synthetic hydroxyapatite (HAP) and alginate hydroxyapatite composite (Alg/Hap) are shown in Figures 5(a)-5(c); respectively. Crystal size was calculated according to Debye-Scherrer equation and listed in Table 2. It should be noted that the particle dimension obtained by HR-TEM is higher than the corresponding calculated crystal size. This difference may be explained by the presence of aggregates in HR-TEM grain consisting of several crystallites [31]. 


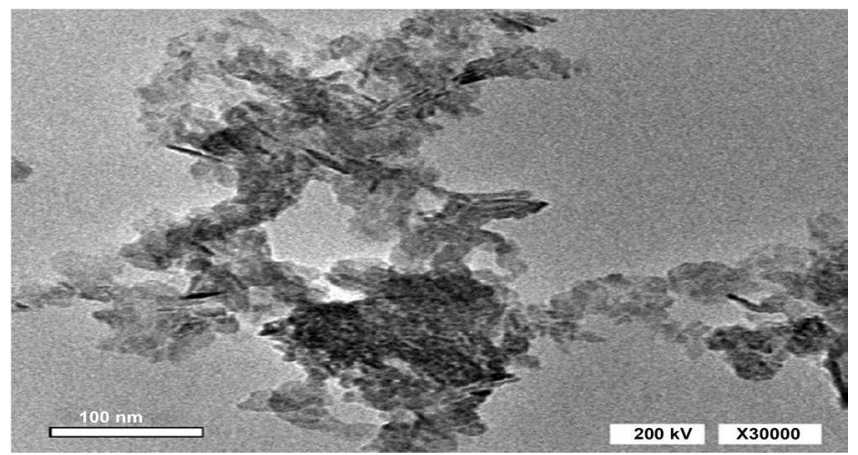

(a)

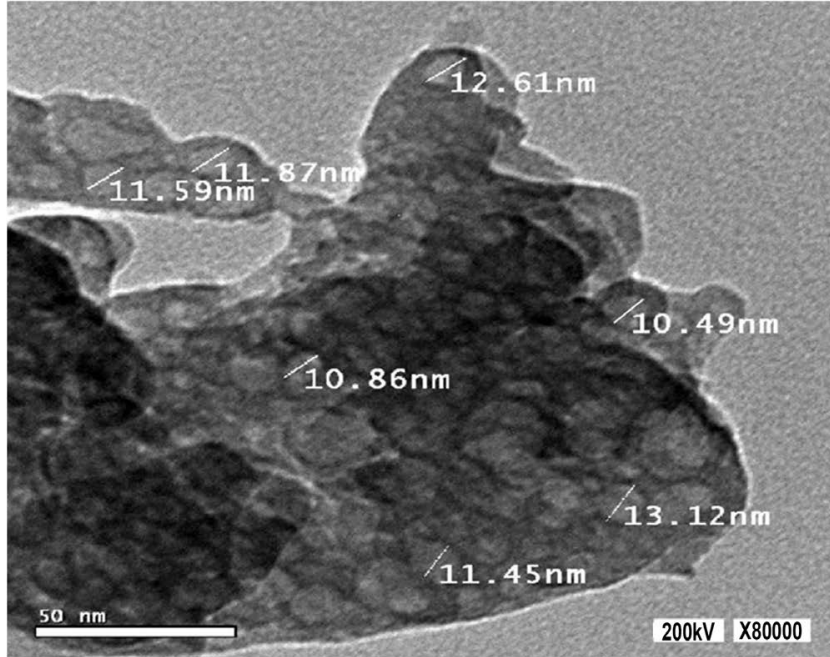

(b)

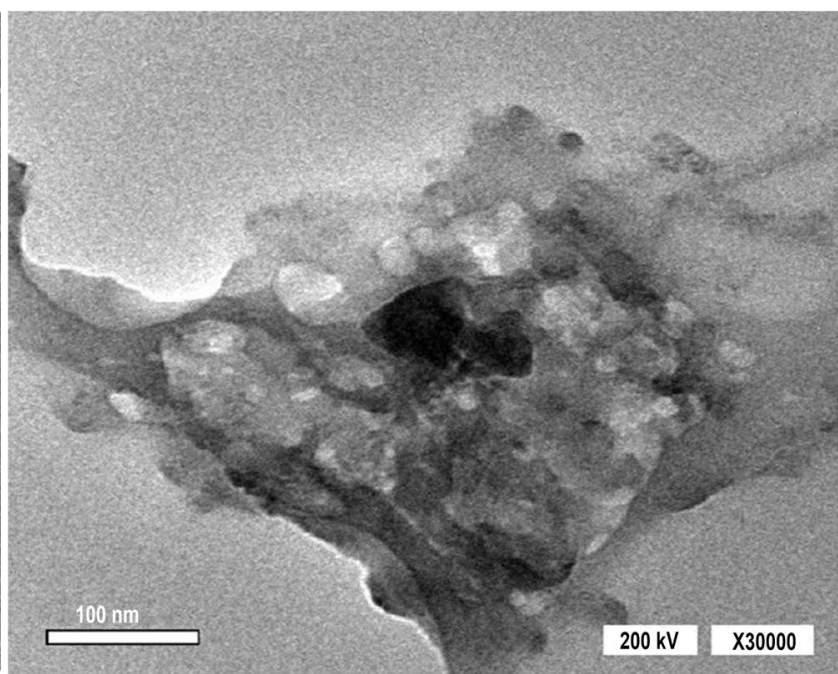

(c)

Figure 3. HR-TEM images of (a) fish bones (F.B), (b) synthetic hydroxyapatite (HAP) and (c) alginate hydroxyapatite composite (Alg/Hap).

Table 1. FT-IR peaks positions and their assignments for different biosorbents.

\begin{tabular}{lccc}
\hline \multirow{2}{*}{ Peak assignment } & \multicolumn{3}{c}{ Peak position wave number $\left(\mathrm{cm}^{-1}\right)$} \\
\cline { 2 - 4 } & \multicolumn{1}{c}{ F.B } & HAP & Alg/Hap \\
\hline Stretching O-H & 3430 & 3470 & 3400 \\
Adsorbed water & $3400-2800$ & 3250 & 3100 \\
Bending mode, $v_{2}$ of adsorbed water & 1658 & 1650 & ---- \\
Stretching mode, $v_{3}$ of $\mathrm{CO}_{3}^{2-}$ group & 1456 & 1410 & 1380 \\
Asymmetric or $v_{3}$ of $\left(\mathrm{PO}_{4}\right)^{3-}$ group & 1030 & 1050 & ---- \\
The O-P-O bands of $\left(\mathrm{PO}_{4}\right)^{3-}$ group & $604-560$ & $630-560$ & 552 \\
$\begin{array}{l}\text { Asymmetric stretching vibration of the carboxylate } \\
(-\mathrm{COO}) \text { groups }\end{array}$ & ---- & ---- & 1630 \\
The C-O-C (cyclic ether) stretching vibration & ---- & ---- & 1040 \\
\hline
\end{tabular}

The strong absorption band at $\left(1630 \mathrm{~cm}^{-1}\right)$ in case of $\mathrm{Alg} / \mathrm{Hap}$ is attributed to asymmetric stretching vibration of the carboxylate $\left(-\mathrm{COO}^{-}\right)$groups on the polymeric backbone. 


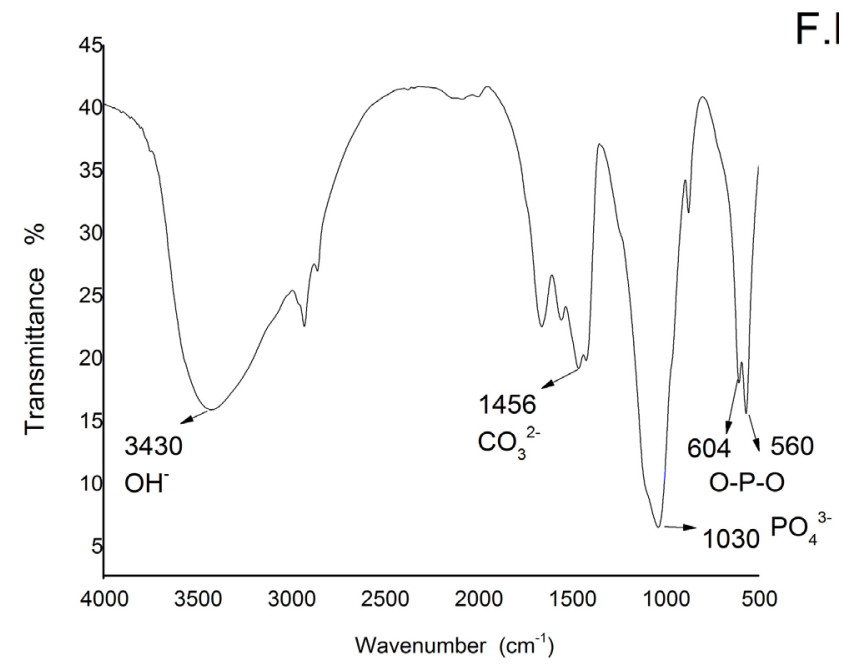

(a)

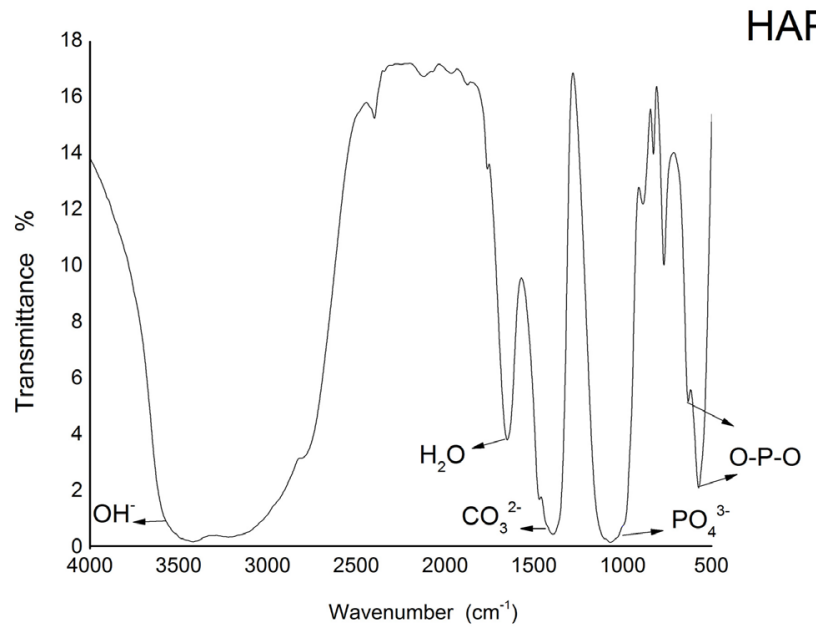

(b)

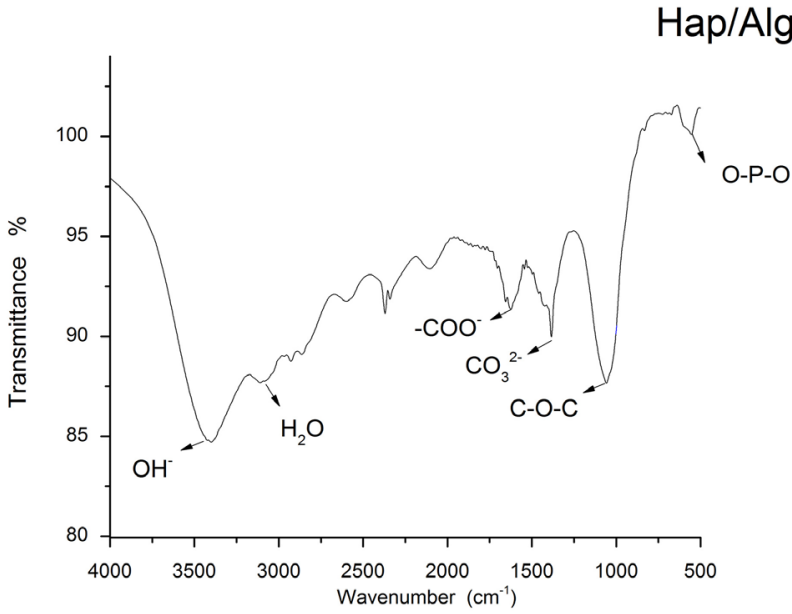

(c)

Figure 4. FT-IR spectrum of (a) fish bones (F.B), (b) synthetic hydroxyapatite (HAP), and (c) alginate hydroxyapatite composite (Alg/Hap).

The absorption band at $\left(1040 \mathrm{~cm}^{-1}\right)$ is attributed to the $\mathrm{C}-\mathrm{O}-\mathrm{C}$ (cyclic ether) stretching vibration. An absorption band can be observed at $\left(552 \mathrm{~cm}^{-1}\right)$ which is attributed to the bending of $\mathrm{PO}_{4}^{3-}$ of $\mathrm{HA}$. The broad band $\left(3100 \mathrm{~cm}^{-1}\right)$ is assigned to stretching of the $-\mathrm{OH}$ groups of absorbed water [30].

The TGA thermograms of the studied biosorbents are shown in Figure 6. The first endothermic region ranged from $30^{\circ} \mathrm{C}$ to $400^{\circ} \mathrm{C}$ was corresponding to the dehydration of the precipitating complex and the loss of physically adsorbed water molecules. The weight loss in this region is approximately $16 \%$ in case of natural fish bone (Figure 6(a)); while this percentage increase slightly in synthetic hydroxyapatite powder due to the remaining water content from the preparation (Figure 6(b)). With increasing temperature from $400^{\circ} \mathrm{C}$ to $600^{\circ} \mathrm{C}$ no peak has been observed, except a weight loss of $4 \%-6 \%$ which is probably due to the gradual hydroxylation in hydroxyapatite powder. 


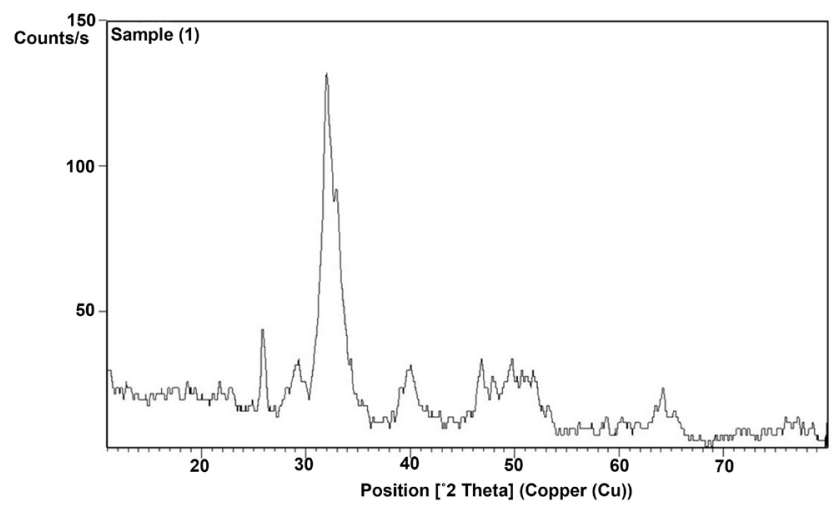

(a)

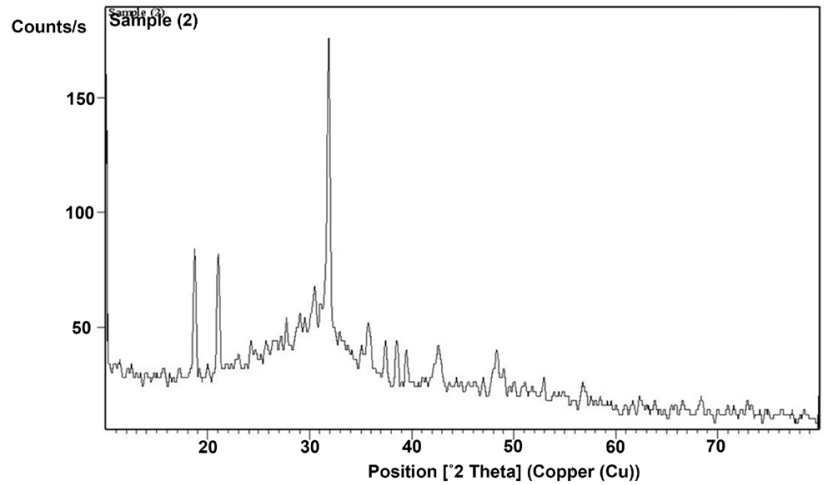

(b)

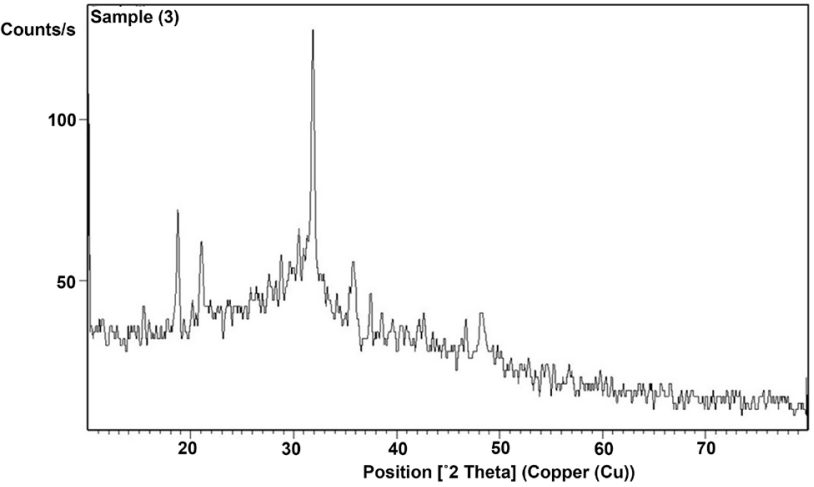

(c)

Figure 5. XRD patterns of (a) fish bones (F.B), (b) synthetic hydroxyapatite (HAP), and (c) alginate hydroxyapatite composite (Alg/Hap)

Table 2. Average Crystal size of basic peaks for different biosorbents.

\begin{tabular}{cccc}
\hline Sorbent & Peak Position (2 Theta) & FWHM $^{*}$ & Average Crystal Size (nm) \\
\hline F.B & 30.17 & 2.30 & 3.75 \\
HAP & 31.85 & 1.17 & 7.33 \\
Alg/Hap & 31.77 & 1.67 & 5.14 \\
\hline
\end{tabular}

FWHM = Full Width at Half Maximum.

The TGA of alginate hydroxyapatite graph (C) shows loss of water below $200^{\circ} \mathrm{C}$ at about $15 \%$. The weight loss between $200^{\circ} \mathrm{C}-400^{\circ} \mathrm{C}$ (around 25\%) indicates the rupture of chains, fragments, and monomers in $\mathrm{Alg} / \mathrm{Hap}$. This step is mainly related to the possible loss of organic content loaded on the surface of hydroxyapatite [34].

\subsection{Biosorption Studies}

\subsubsection{Effect of the Medium pH on the Metal Biosorption Capacity}

The effect of $\mathrm{pH}$ value of contact solution on the metal sorption capacity values was studied in various acidic and neutral solutions at different $\mathrm{pH} 1.0-7.0$ as plotted in Figure 7(a) \& Figure 7(b). The results of this study for $\mathrm{Pb}(\mathrm{II})$ are 


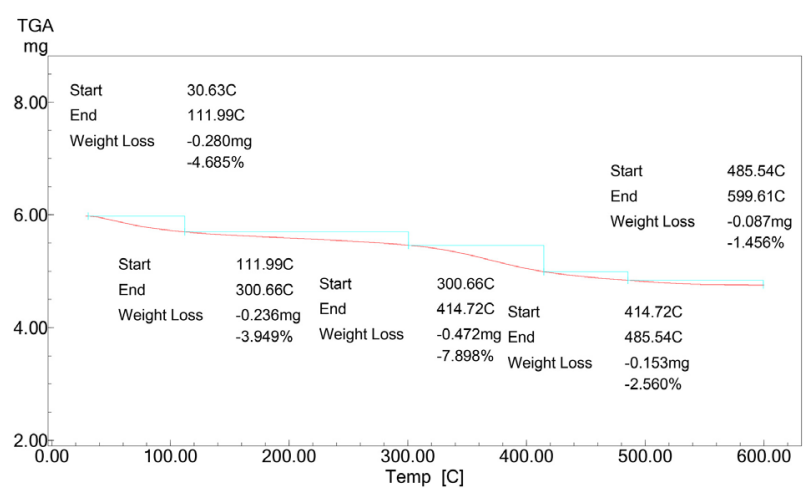

(a)

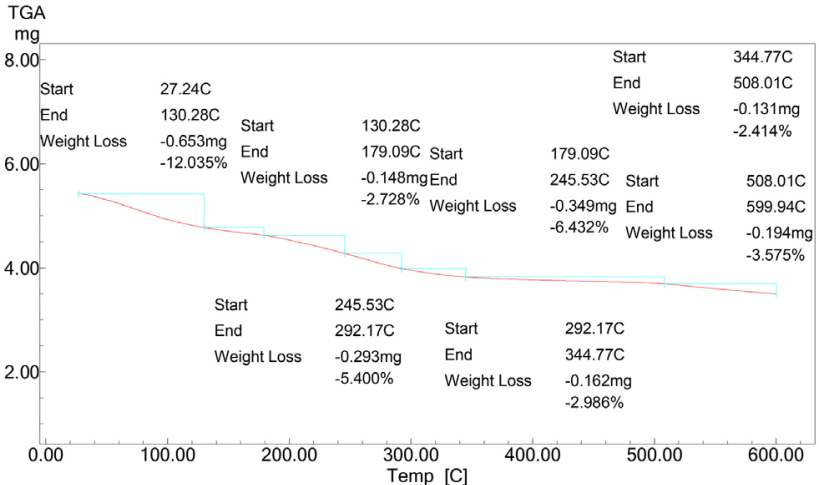

(b)

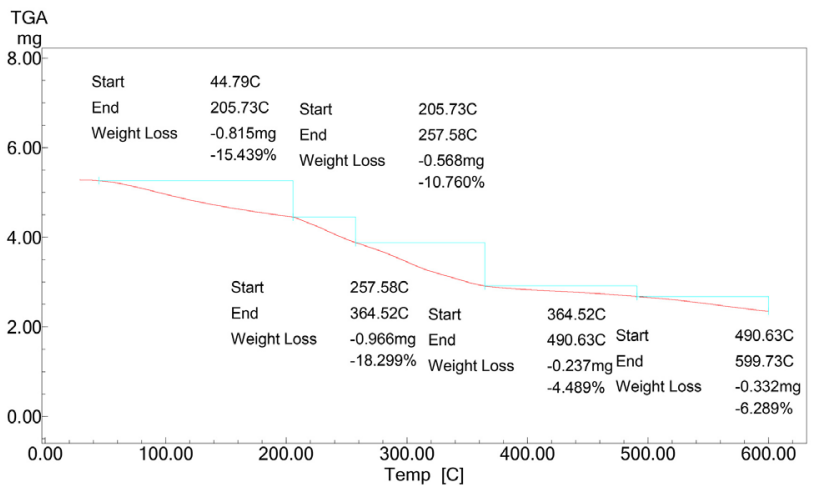

(c)

Figure 6. TGA-Thermograms of (a) fish bones (F.B), (b) synthetic hydroxyapatite (HAP), and (c) alginate hydroxyapatite composite (Alg/Hap).

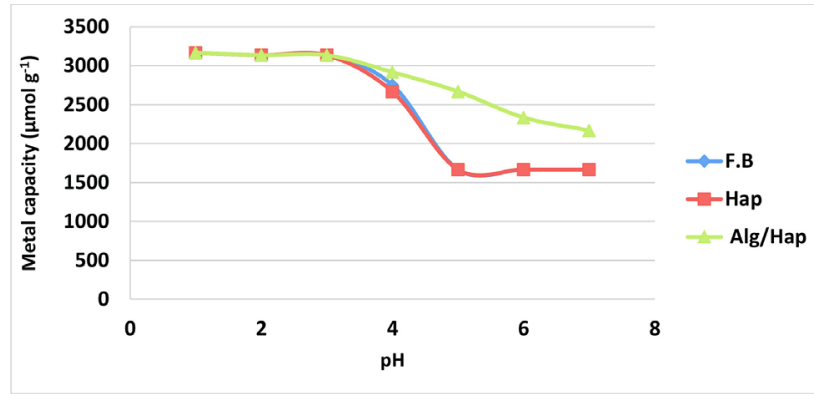

(a)

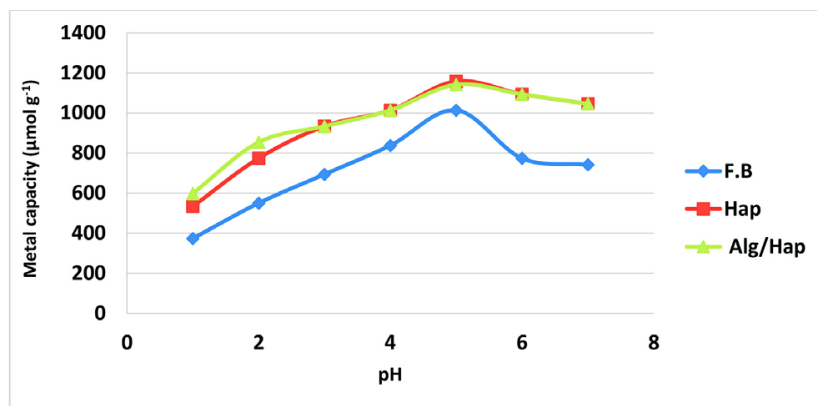

(c)

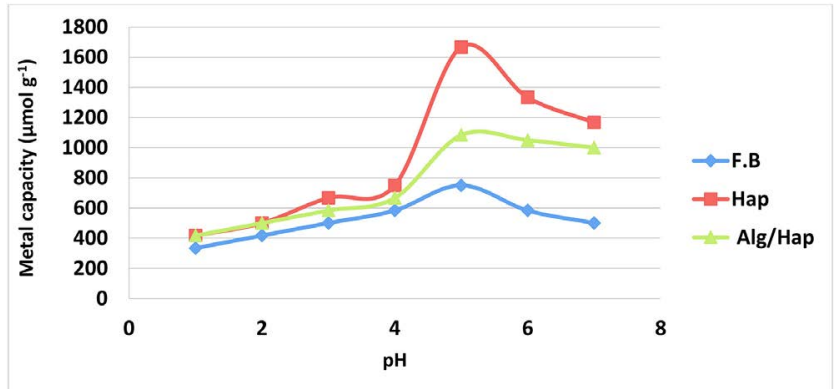

(b)

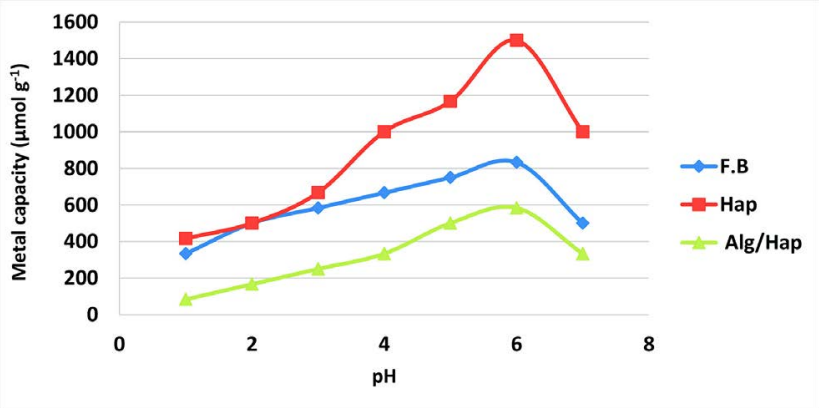

(d)

Figure 7. Effect of the $\mathrm{pH}$ on (a) $\mathrm{Pb}(\mathrm{II})$, (b) $\mathrm{Cd}(\mathrm{II}),(\mathrm{c}), \mathrm{Cr}(\mathrm{VI}),(\mathrm{d}) \mathrm{Hg}(\mathrm{II})$ biosorption capacities by various biosorbents. 
shown in Figure 7(a). The efficiency of all biosorbents towards lead (II) removal was strongly affected by the solution $\mathrm{pH}$. As a general trend, the maximum sorption capacity values were observed at $\mathrm{pH} 1$. In addition, the lead sorption was found to gradually decrease from $\mathrm{pH} 1$ to $\mathrm{pH} 3$ followed by a significant decrease to a minimum value at $\mathrm{pH}$ 7. The high sorption capacity values observed at lower $\mathrm{pH}$ values $(\mathrm{pH}<7)$; where the biosorbents are positively charged; are attributed to the predominance of the cation exchange mechanism [35]. On the other hand, the effect of $\mathrm{pH}$ on the $\mathrm{Cd}(\mathrm{II})$ sorption capacity indicated that the maximum biosorption capacities of various investigated biosorbents were observed at pH 5 (Figure 7(b)). The metal biosorption was found to gradually increase from $\mathrm{pH} 1$ to $\mathrm{pH} 4$, followed by a dramatic rising in the biosorption capacity values by the $\mathrm{pH} 5$ and $\mathrm{pH}$ 6. By increasing the $\mathrm{pH}$ value to $\mathrm{pH} 7$, maximum biosorption capacity values were obtained by the studied and evaluated biosorbents. In addition, at low $\mathrm{pH}$, the low sorption capacity values are attributed to the interference caused by the high concentration of hydrogen ions which occupy active binding sites leading to inhibition of metal sorption. The significant increase in metal ions uptake in the range of $\mathrm{pH} 4-7$, is mainly due to increasing the active binding sites by deprotonation of the surface functional groups occurred at higher $\mathrm{pH}[32]$.

The results indicated also that the maximum biosorption capacities of various investigated biosorbents were observed at $\mathrm{pH} 5$ for $\mathrm{Cr}(\mathrm{VI})$ and $\mathrm{pH} 6$ for $\mathrm{Hg}(\mathrm{II})$. The metal biosorption was found to gradually increase from $\mathrm{pH} 1$ to $\mathrm{pH} 4$, followed by a dramatic rising in the biosorption capacity valuesin case of $\mathrm{Cr}(\mathrm{VI})$ at $\mathrm{pH} 5$ and $\mathrm{pH} 6$ in case of $\mathrm{Hg}(\mathrm{II})$. Worth mentioning that the low sorption capacity values at low $\mathrm{pH}$ values are attributed to the interference caused by the high concentration of hydrogen ions which occupy active binding sites leading to inhibition of metal sorption [36]. The significant increase in metal ions uptake in the range of $\mathrm{pH} 4-7$, is mainly due to increasing the active binding sites by deprotonation of the surface functional groups occurred at higher $\mathrm{pH}$ [32].

The functional groups responsible for binding with heavy metal ions are generally in the form of hydroxyl $(-\mathrm{OH})$, phosphate $\left(\mathrm{PO}_{4}^{3-}\right)$, carbonate $\left(\mathrm{CO}_{3}^{2-}\right)$ in the three phases and carboxylate $\left(-\mathrm{COO}^{-}\right)$for $\mathrm{Alg} / \mathrm{Hap}$ only. Two dominant mechanisms for the ability of HAP to take up divalent cations have been proposed [36]. The first mechanism is the adsorption of metal ions on the HAP surfaces following an ion exchange reaction between metal ions adsorbed and $\mathrm{Ca}(\mathrm{II})$ ions of HAP. These ion exchange reaction mechanisms are expressed as:

$$
\mathrm{Ca}_{10}\left(\mathrm{PO}_{4}\right)_{6}(\mathrm{OH})_{2}+\mathrm{xM}^{2+} \rightarrow \mathrm{xCa}^{2+}+\mathrm{Ca}_{10-\mathrm{x}} \mathrm{M}_{\mathrm{x}}\left(\mathrm{PO}_{4}\right)_{6}(\mathrm{OH})_{2}
$$

The second mechanism is the dissolution of HAP in aqueous solution containing metal ions followed by precipitation such as hydroxyl pyromorphite $\left[\mathrm{Pb}_{10}\left(\mathrm{PO}_{4}\right)_{6}(\mathrm{OH})_{2}, \mathrm{HPy}\right]$ in case of solution containing $\mathrm{Pb}(\mathrm{II})$ i.e., the dissolution-precipitation mechanism, which is written as:

Dissolution:

$$
\mathrm{Ca}_{10}\left(\mathrm{PO}_{4}\right)_{6}(\mathrm{OH})_{2}+14 \mathrm{H}^{+} \rightarrow 10 \mathrm{Ca}^{2+}+6 \mathrm{H}_{2} \mathrm{PO}_{4}^{-}+2 \mathrm{H}_{2} \mathrm{O}
$$


Precipitation:

$$
10 \mathrm{~Pb}^{2+}+6 \mathrm{H}_{2} \mathrm{PO}_{4}^{-}+2 \mathrm{H}_{2} \mathrm{O} \rightarrow 14 \mathrm{H}^{+}+\mathrm{Pb}_{10}\left(\mathrm{PO}_{4}\right)_{6}(\mathrm{OH})_{2}
$$

The comparable study of all investigated biosorbents towards $\mathrm{Pb}(\mathrm{II})$, and $\mathrm{Cd}(\mathrm{II})$ biosorption indicates that:

- The optimum buffering condition of all biosorbents for $\mathrm{Pb}(\mathrm{II})$ removal is $\mathrm{pH}$ 1; while that for $\mathrm{Cd}(\mathrm{II})$ is $\mathrm{pH} 5$ at which each biosorbent exhibit maximum metal sorption capacity.

- The maximum $\mathrm{Pb}(\mathrm{II})$ sorption capacity values of all biosorbents are similar in the beginning (at low $\mathrm{pH}$ values) but have slightly difference in the ending as the following order: Alg/Hap > F.B > HAP.

While, that for Cd(II) removal are in the order of: HAP > Alg/Hap > F.B.

- The maximum $\mathrm{Cr}(\mathrm{VI})$ sorption capacity values of all biosorbents are in the order of: HAP $=\mathrm{Alg} / \mathrm{Hap}>\mathrm{F} . \mathrm{B}$. While, that for $\mathrm{Hg}(\mathrm{II})$ removal are in the order of: HAP > F.B > Alg/Hap.

\subsubsection{Effect of the Reaction Contact Time on the Metal Biosorption Capacity}

To identify the change in biosorption capacity values versus the contact time factor, the metal ion solution was shaken with $30 \pm 1 \mathrm{mg}$ of each biosorbents, F.B, HAP, Alg/Hap at different times. The sorption capacity values $\left(\mu \mathrm{mol} \cdot \mathrm{g}^{-1}\right)$ of $\mathrm{Pb}(\mathrm{II}), \mathrm{Cd}(\mathrm{II}), \mathrm{Cr}(\mathrm{VI})$ and $\mathrm{Hg}(\mathrm{II})$ as a function of reaction contact time are shown in Figures 8(a)-(d). The metal ions uptake processes by all biosorbents were found to proceed with high rate of metal sorption capacity values after 5 min of the contact time. The interaction between metal ions and the biosorbent was generally found to proceed via two successive stages. The first stage involves a rapid increase in the removal efficiency of the metal ions onto biosorbents due to the abundant availability of active binding sites on biosorbent surface, and with gradual occupancy of these sites, the metal biosorption become less efficient. The second stage, at which the equilibrium is reached, is mainly based on the complete saturation $(100 \%)$ of the biosorbent surface with the target metal ions. The fast operating time is one of the advantages of using these investigated biosorbentsas the biosorption equilibrium of each metal ion with all biosorbents were established within $\sim 15$ - 20 minutes. The maximum biosorption values of $\mathrm{Pb}$ (II) obtained at equilibrium are the same for all three biosorbents and equal $2785 \mu \mathrm{mol} \cdot \mathrm{g}^{-1}$; while the maximum sorption values of $\mathrm{Cd}(\mathrm{II})$ obtained at equilibrium are 675,1250 and $812 \mu \mathrm{mol} \cdot \mathrm{g}^{-1}$ for F.B, HAP and Alg/Hap; respectively. On the meantime, the maximum biosorption values of $\mathrm{Cr}(\mathrm{VI})$ obtained at equilibrium are 1013, 1109 and $1221 \mu \mathrm{mol} \cdot \mathrm{g}^{-1}$ for F.B, HAP and Alg/Hap; respectively. While the maximum biosorption values of $\mathrm{Hg}$ (II) obtained at equilibrium are 866,1533 and $583 \mu \mathrm{mol} \cdot \mathrm{g}^{-1}$ for F.B, HAP and Alg/Hap; respectively. In the light of the above, it can be concluded that one of the vital advantages of these biosorbents as solid phase extractors is saving operation time (about $20 \mathrm{~min}$ ). 


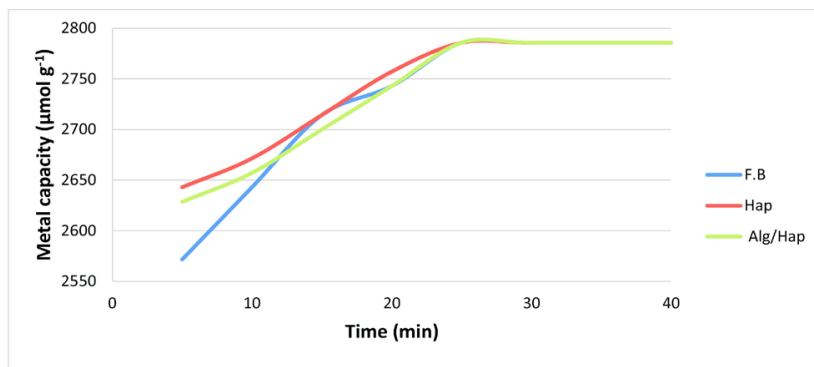

(a)

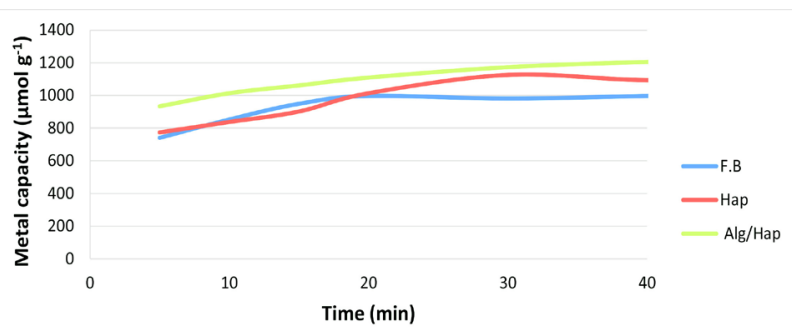

(c)

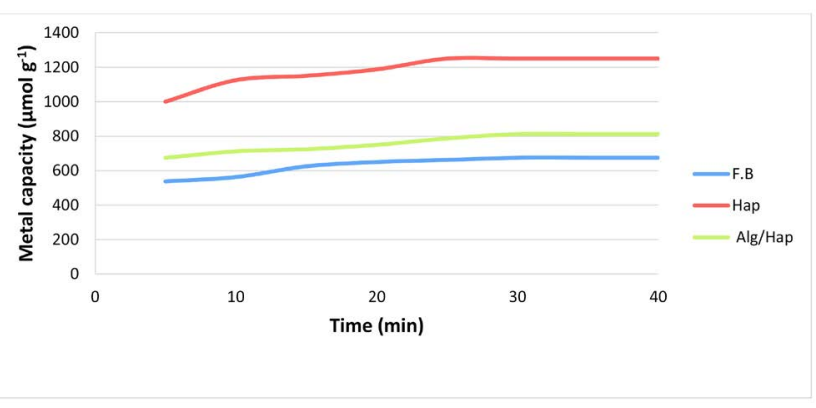

(b)

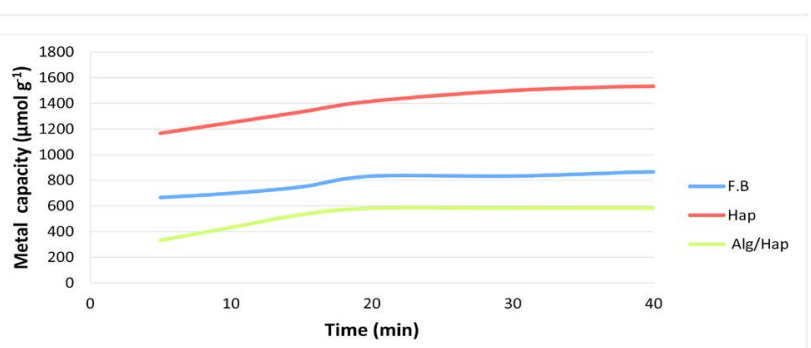

(d)

Figure 8. Effect of the contact time on (a) $\mathrm{Pb}(\mathrm{II})$, (b) $\mathrm{Cd}(\mathrm{II})$, (c) $\mathrm{Cr}$ (VI), and (d) $\mathrm{Hg}$ (II) biosorption capacities by various biosorbents.

\subsubsection{Effect of the Biosorbent Dosage on the Metal Biosorption Capacity} The effect of the biosorbent dosage on the biosorption capacity values were investigated under optimum buffering conditions for each metal ion by different biosorbent doses $\left(5-50 \mathrm{mg}\right.$ ) with initial concentration $\left(0.1 \mathrm{~mol} \cdot \mathrm{L}^{-1}\right)$ of each metal ion (Figures 9(a)-(d)). The maximum biosorption capacity was achieved when $5 \mathrm{mg}$ biosorbent dose was used.

Based on the previous results, it can be concluded that the biosorption capacity values of the examined metal ions showed a decreasing order with increasing the biosorbent dosage until achieve equilibrium [37]. However, the high determined metal biosorption capacity values in lower biosorbent doses (5 and 10 $\mathrm{mg}$ ) are mainly due to the high availability of metal ion solution compared to the exposed surface area as well as active centers. In the case of high sorbent dose (50 $\mathrm{mg}$ ), the opposite trend was observed. This behavior may be attributed to the formation of aggregates during biosorption causing a direct decrease in the effective uptake with respect to the exposed surface area at high biosorbent dosage [29] [38].

\subsubsection{Effect of Interfering Ions on the Metal Biosorption Capacity}

The effect of matrix or interfering ions can be presented by a competitive study for the sorption of the metal ion under study in presence of other interfering cations. A number of competing species were used in this study including $\mathrm{Na}(\mathrm{I})$, $\mathrm{K}(\mathrm{I}), \mathrm{Ca}(\mathrm{II})$ and $\mathrm{Mg}(\mathrm{II})$ by using equimolar concentration of each metal ion. This study was performed at optimum conditions for each metal ion by various 


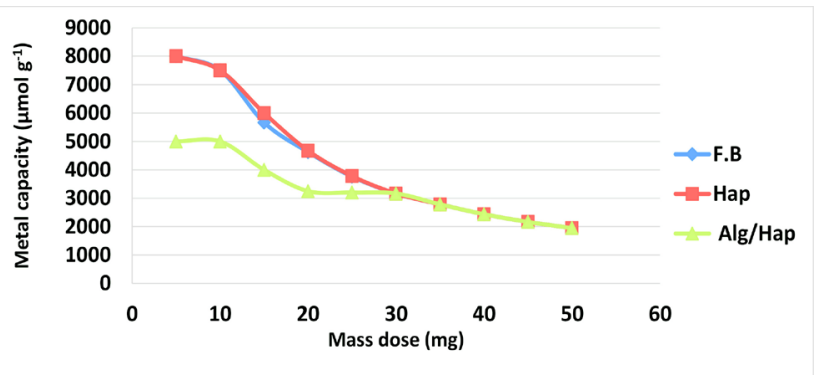

(a)

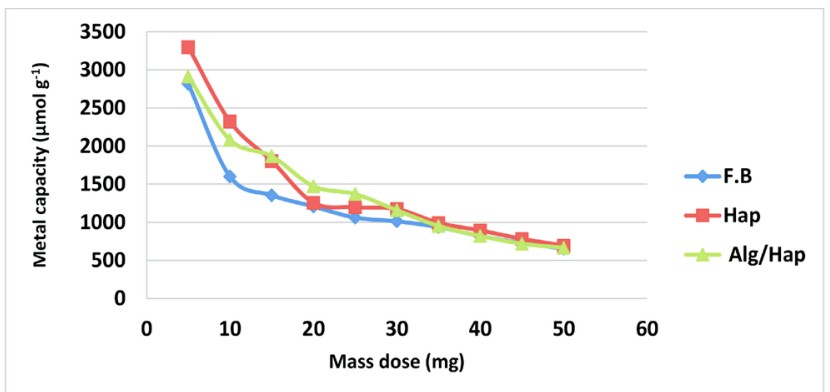

(c)

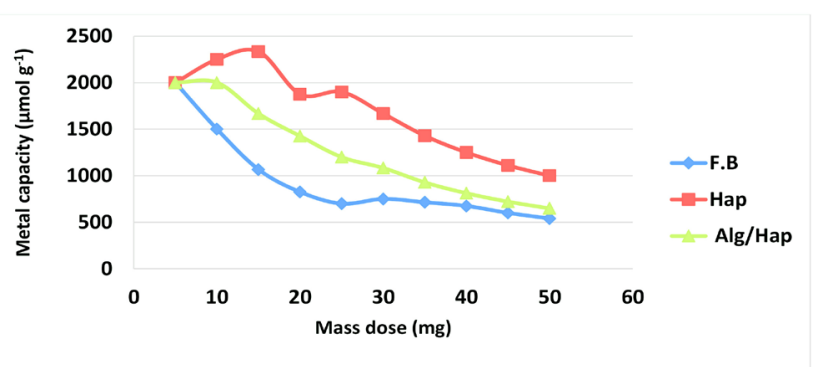

(b)

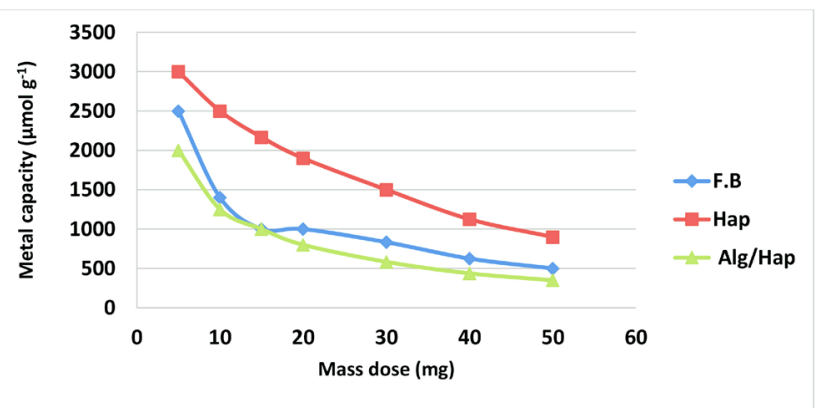

(d)

Figure 9. Effect of the biosorbent dosage on (a) $\mathrm{Pb}(\mathrm{II})$, (b) $\mathrm{Cd}(\mathrm{II})$, (c) $\mathrm{Cr}$ (VI), and (d) $\mathrm{Hg}$ (II) biosorption capacities by various biosorbents.

biosorbents, F.B, HAP, and Alg/Hap (Figures 10(a)-(d)). The results of the metal biosorption capacity values in presence of an interfering ion and the value obtained in absence of the interfering ion for $\mathrm{Pb}(\mathrm{II}), \mathrm{Cd}(\mathrm{II}), \mathrm{Cr}$ (VI) and $\mathrm{Hg}$ (II) are listed in Table 3. It was found that $\mathrm{Na}(\mathrm{I})$ and $\mathrm{K}(\mathrm{I})$ causing limited inference behaviors compared to $\mathrm{Ca}(\mathrm{II})$ and $\mathrm{Mg}(\mathrm{II})$. The different affinities of interfering ions in competitive biosorption are due to the difference in their ionic charges and ionic radii as well as the nature of functional groups present on the biosorbent [39].

The results of the present study confirmed that the effect of interfering ions on the metal biosorption by different biosorbents is based on the following order: $\mathrm{Ca}^{2+}>\mathrm{Mg}^{2+}>\mathrm{K}^{+}>\mathrm{Na}^{+}$.

\subsection{Potential Applications of Biosorbents for Removal of $\mathrm{Pb}, \mathrm{Cd}$, $\mathrm{Cr}(\mathrm{VI})$, and $\mathrm{Hg}$ (II) Ions from Water Samples}

The potential applications of the biosorbents for removal and sorption of $\mathrm{Pb}, \mathrm{Cd}$, $\mathrm{Cr}(\mathrm{VI})$, and $\mathrm{Hg}$ (II) from seawater samples were studied. The concentrations of $\mathrm{Pb}$ and $\mathrm{Cd}$ ions in water samples before removal are illustrated in Table 4.

In general, the slight decrease in the removal values of $\mathrm{Pb}$ and $\mathrm{Cd}$ ions from the seawater samples compared to those obtained in the case of the synthetic seawater sample may be attributed to the possibility of presence of other interfering ions such as sulfate, phosphate, or other nutrients in the seawater which compete with the metal ions towards the active binding sites on the biosorbent surface. 


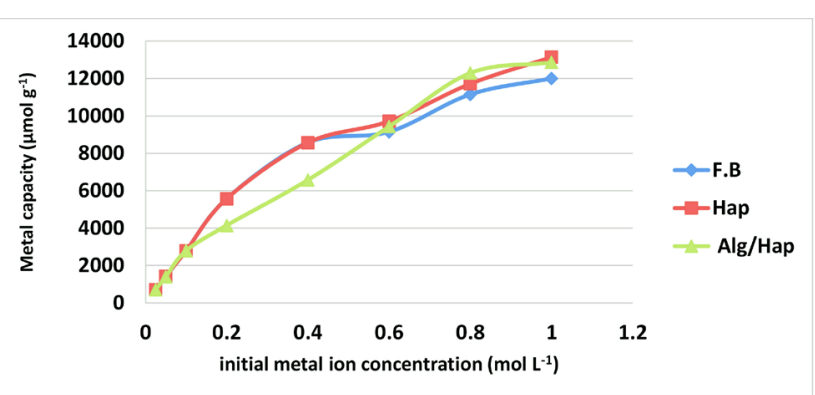

(a)

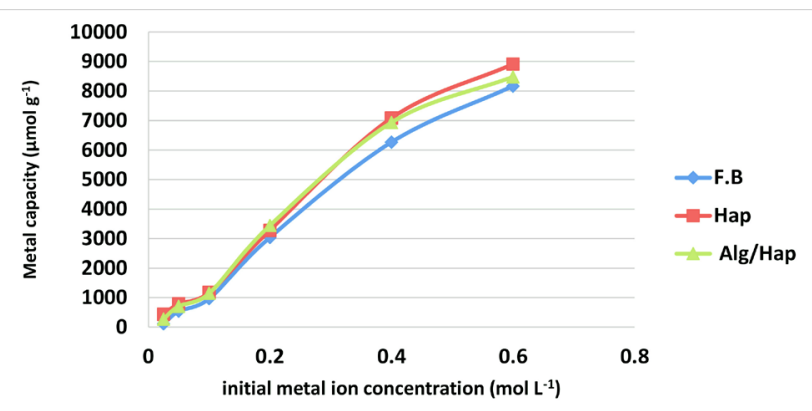

(c)

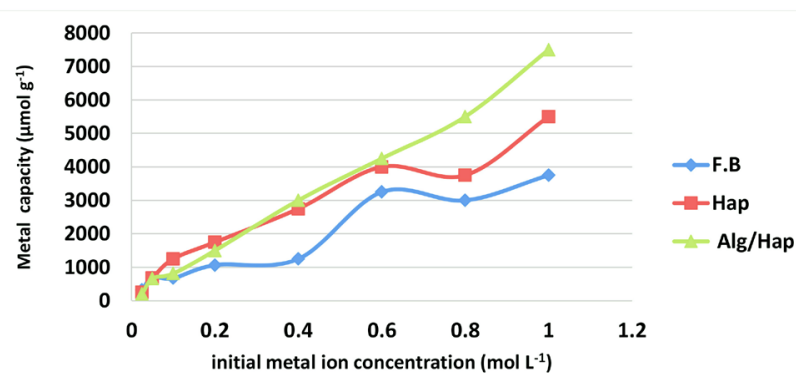

(b)

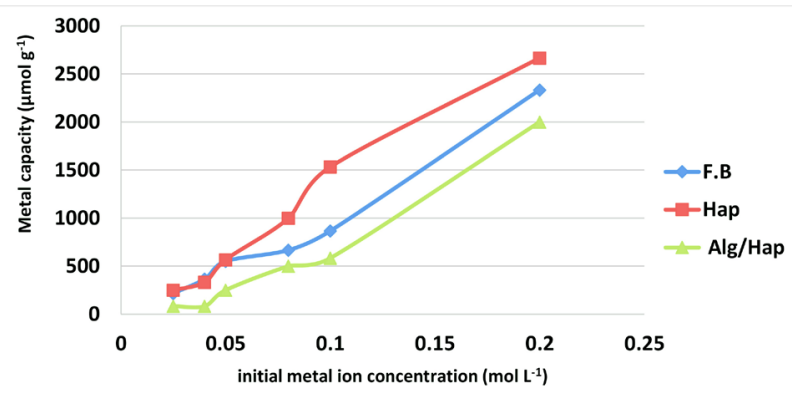

(d)

Figure 10. Effect of initial metal ion concentration (a) $\mathrm{Pb}(\mathrm{II})$, (b) $\mathrm{Cd}(\mathrm{II})$, (c) $\mathrm{Cr}(\mathrm{VI})$ and (d) $\mathrm{Hg}(\mathrm{II})$ biosorption capacities by various biosorbents.

Table 3. Effect of interfering ions on (a) $\mathrm{Pb}(\mathrm{II})$, (b) $\mathrm{Cd}$ (II), (c) $\mathrm{Cr}(\mathrm{VI})$ and $\mathrm{Hg}$ (II) biosorption capacity.

\begin{tabular}{|c|c|c|c|c|c|c|c|c|c|c|c|c|}
\hline $\begin{array}{l}\text { Interfering } \\
\text { ions }\end{array}$ & $\mathrm{Pb}(\mathrm{II})$ & $\begin{array}{c}\text { Biosorption } \\
\left(\mu \mathrm{mol} \cdot \mathrm{g}^{-1}\right)\end{array}$ & Capacity & $\mathrm{Cd}(\mathrm{II})$ & $\begin{array}{c}\text { Biosorption } \\
\left(\mu \mathrm{mol} \cdot \mathrm{g}^{-1}\right)\end{array}$ & Capacity & $\mathrm{Cr}(\mathrm{VI})$ & $\begin{array}{c}\text { Biosorption } \\
\left(\mu \mathrm{mol} \cdot \mathrm{g}^{-1}\right)\end{array}$ & Capacity & $\mathrm{Hg}(\mathrm{II})$ & $\begin{array}{c}\text { Biosorption } \\
\left(\mu \mathrm{mol} \cdot \mathrm{g}^{-1}\right)\end{array}$ & Capacity \\
\hline & F.B & HAP & Alg/Hap & F.B & HAP & Alg/Hap & F.B & HAP & Alg/Hap & F.B & HAP & Alg/Hap \\
\hline $\mathrm{Na}(\mathrm{I})$ & 2685 & 2742 & 2657 & 650 & 1125 & 750 & 917 & 1141 & 1093 & 833 & 1466 & 533 \\
\hline $\mathrm{K}(\mathrm{I})$ & 2628 & 2714 & 2614 & 637 & 1075 & 712 & 869 & 1109 & 1061 & 816 & 1423 & 483 \\
\hline $\mathrm{Ca}$ (II) & 2108 & 2154 & 2042 & 577 & 1017 & 637 & 645 & 981 & 933 & 747 & 1244 & 304 \\
\hline $\mathrm{Mg}(\mathrm{II})$ & 2174 & 2271 & 2148 & 587 & 1039 & 665 & 725 & 1013 & 949 & 771 & 1323 & 336 \\
\hline
\end{tabular}

The extractions of metal ions were successfully accomplished by triplicate analysis via a multi-stages micro-column system and the percentage extraction values by different biosorbents for each metal ion (Table 4). It is important to report here that the fish bones (F.B) (Natural Hydroxyapatite), synthetic hydroxyapatite (HAP), and modified hydroxyapatite (Alg/Hap) biosorbents exhibited high efficiency for removal of different metal ions (>90\%).

\section{Conclusion}

The current work describes a method to prepare nanopowder of natural hydroxyapatite from fish bone of the tilapia (F.B), to synthesis the same substance (HAP) chemically and prepare the hydroxyapatite composite with alginic acid (Alg/Hap) to use as biosorbent materials. The modified sorbents were used for 
Table 4. Comparative study of concentrations of $\mathrm{Pb}(\mathrm{II})\left(\mathrm{mg} \cdot \mathrm{L}^{-1}\right), \mathrm{Cd}(\mathrm{II})\left(\mathrm{mg} \cdot \mathrm{L}^{-1}\right), \mathrm{Cr}(\mathrm{VI})$, and $\mathrm{Hg}(\mathrm{II})$ in different water samples before removal and after using F.B (\%), HAP (\%), and Alg/HAP (\%).

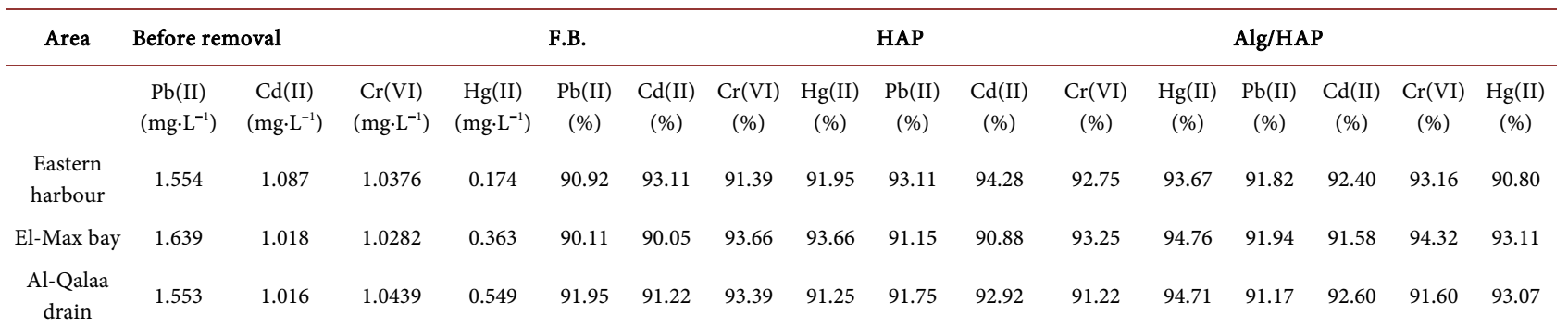

sorption and solid phase extraction of $\mathrm{Pb}$ (II) and $\mathrm{Cd}(\mathrm{II})$ ions. Surface characterization and modification were examined and confirmed by using the SEM, HR-TEM, FT-IR, XRD, and TGA. The biosorption studies were studied and accomplished by using the batch techniques for removal and selective extraction of the metal ions previously mentioned. Various experimental factors affecting biosorption capacity such as solution $\mathrm{pH}$, contact time, biosorbent dosage, initial metal concentration and presence of competitive ions were studied. Removal of $\mathrm{Pb}$ (II) ions was observed to selectively carried out at $\mathrm{pH} 1-2$. The removal percentage values of different metal ions were $>90 \%$ even in presence of other interfering ions

\section{Conflicts of Interest}

The authors declare no conflicts of interest regarding the publication of this paper.

\section{References}

[1] Wahby, S.D. and Shriadach, M.A. (1984) The Effect of Sewage Discharge on Some Chemical Characteristics of Seawater. VII Journees Etud Pollutions, Lvcerene. CIESM, 81-90.

[2] Shriadah, M.A. and Ohzeki, K. (1986) Determination of Iron in Seawater by Densitometery after Enrichment as a Bathophenenthroline-Disulphonate Complex on a Thin Layer of Anion-Exchange Resin. Analyst, 111, 555-558. https://doi.org/10.1039/an9861100555

[3] Fahmy, M.A., Tayel, F.T. and Shriadah, M.A. (1995) Effect of Pollution on the Water Quality of Mex Bay and Dekhaila Harbor of Alexandria. 1st International Conference on Present and Future Technology of Navigation and Marine Science of Mediterranean and the Red Sea, Egypt, 29-31 October 1995.

[4] ElDeeb, M.K.Z., Said, T.O., El Naggar, M.H. and Shreadah, M.A. (2007) Distribution and Sources of Apliphatic and Polycyclic Aromatic Hydrocarbons in Surface Sediments, Fish and Bivalves of Abu Qir Bay. Bulletin of Environmental Contamination and Toxicology, 78, 373-379. https://doi.org/10.1007/s00128-007-9173-Z

[5] Abdel Ghani, S.A., Shobier, A.H., Said, T.O. and Shreadah, M.A. (2010) Organotin Compounds in Egyptian Mediterranean Sediments. Egyptian Journal of Aquatic Research, 36, 221-229.

[6] AbdelGhani, S.A., Shobier, A.H. and Shreadah, M.A. (2013) Assessment of Arsenic and Vanadium Pollution in Surface Sediments of the Egyptian Mediterranean Coast. 
Journal of Environmental Technology and Management, 16, 82-101. https://doi.org/10.1504/IJETM.2013.050673

[7] Abdel Salam, S., El Zokm, G., Shobier, A., Othman, T. and Shreadah, M.A. (2013) Metal Pollution in Surface Sediments of Abu Qir Bay and the Eastern Harbour of Alexandria, Egypt. The Egyptian Journal of Aquatic Research, 39, 1-12. https://doi.org/10.1016/j.ejar.2013.03.001

[8] Abd ElMoneam, N.M., Abd ElMaguid, N.E., El-Sikaily, A.M., Zaki, M.G. and Shreadah, M.A. (2016) Biomarkers and Ultra Structural Evaluation of Marine Pollution by Polycyclic Aromatic Hydrocarbons. Journal Environmental Protection, 7, 1283-1304. https://doi.org/10.4236/jep.2016.710113

[9] Shreadah, M.A., El-Sikaily, A.M., Abd El Moneam, N.M., Abd El Maguid, N.E. and Zaki, M.G. (2017) Polycyclic Aromatic and Aliphatic Hydrocarbons in Two Egyptian Coastal Areas along the Mediterranean Sea. Expert Opinion Environmental Biology, 6, 2. https://doi.org/10.4172/2325-9655.1000145

[10] Emara, H.I. and Shriadah, M.A. (1991) Manganese, Iron, Cobalt, Nickel, and Zinc in the Eastern Harbor and El-Mex Bey Waters (Alexandria). International Proceedings Symposium of Marine Chemistry in the Arab Region, Suez, April 1991, 97-112.

[11] Shriadah, M.A. and Emara, H.I. (1991) The Distribution of Chromium, Copper, Cadmium, and Lead in Areas of Multi-Polluting Factors of Alexandria. International Proceedings Symposium of Marine Chemistry in the Arab Region, Suez, April 1991, 30-50.

[12] Shriadah, M.A. and Emara, H.I. (1996) Heavy Metals (Iron, Manganese, Nickel, Cadmium, and Lead) in the Sediments from the Eastern harbor and El-Mex Bay of Alexandria, Egypt. Proceedings of 6th International Symposium: Environmental Protection Is a Must, Alexandria, Egypt, 21-23 May 1996, 916-927.

[13] Emara, H.I., Shriadah, M.A., Moustafa, T.H. and El-Deek, M.S. (1995) Trace Metals-Nutrient Salts Relationship in Coastal Seawater of Alexandria. MEDCOAST, Tarragona, Spain, 24-27 October 1995, 1457-1464.

[14] Shriadah, M.A. (1999) Occurrence of Trace Metals in the Arabian Gulf and the Gulf of Oman Sediments off the United Arab Emirates. Oebailla, 25, 43-52.

[15] Shriadah, M.A., Said, T.O., Younis, A.M. and Farag, R.S. (2006) Speciation of Organotin Compounds in Sediments of Semi-Closed Areas along the Mediterranean Coast of Alexandria. Chemistry and Ecology, 22, 395-404. https://doi.org/10.1080/02757540600917443

[16] Shreadah, M.A., Said, T.O., Abd El Ghani, S.A. and Ahmed, A.M. (2008) Alkyllead and Alkyltin Species in Different Fishes Collected from the Suez Gulf, Egypt. Egyptian Journal Aquatic Research, 34, 64-73.

[17] Masoud, M.S., Said, T.O., El-Zokm, G. and Shreadah, M.A. (2010) Speciation of Fe, $\mathrm{Mn}$ and $\mathrm{Zn}$ in Surficial Sediments from the Egyptian Red Sea Coasts. Chemical Speciation and Biodiversity, 22, 257-269. https://doi.org/10.3184/095422910X12894975123773

[18] Khalil, M.K., ElZokm, G.M., Fahmy, M.A., Said, T.O. and Shreadah, M.A. (2013) Geochemistry of Some Major and Trace Elements in Sediments of Edku and Mariut Lakes, North, Egypt. World Applied Sciences Journal, 24, 282-294.

[19] Shreadah, M.A., Fahmy, M.A. and Fattah, L. (2015) Heavy Metals in Some Fish Species and Bivalves from the Mediterranean Coast of Egypt. Journal of Environmental Protection, 6, 1-9. https://doi.org/10.4236/jep.2015.61001

[20] Taha, A.A., Shreadah, M.A., Heiba, H.F. and Ahmed, A.M. (2016) Multi-Component Adsorption of $\mathrm{Pb}(\mathrm{II}), \mathrm{Cd}(\mathrm{II})$, and $\mathrm{Ni}(\mathrm{II})$ onto Egyptian Na-Activated Bentonite; 
Equilibrium, Kinetics, Thermodynamics, and Application for Seawater Desalination. Journal of Environmental Chemical Engineering, 4, 1166-1180. https://doi.org/10.1016/j.jece.2016.01.025

[21] Taha, A.A., Shreadah, M.A., Heiba, H.F. and Ahmed, A.M. (2017) Validity of Egyptian Na-Montmorillonite for Adsorption of $\mathrm{Pb}^{2+}, \mathrm{Cd}_{2+}$ and $\mathrm{Ni}^{2+}$ under Acidic Conditions: Characterization, Isotherm, Kinetics, Thermodynamics and Application Study. Asia-Pacific Journal of Chemical Engineering, 12, 292-306.

https://doi.org/10.1002/apj.2072

[22] Yakout, A.A., El-Sokkary, R.H., Shreadah, M.A. and Abdel Hamid, O.G. (2016) Removal of $\mathrm{Cd}(\mathrm{II})$ and $\mathrm{Pb}(\mathrm{II})$ Ions from Wastewater of Different Matrices by Using Triethylenetetramine Functionalized Cellulose Acetate Crafted Copolymer-Manganese Dioxide Composite. Carbohydrate Polymer, 148, 406-414.

https://doi.org/10.1016/j.carbpol.2016.04.038

[23] Yakout, A.A., El-Sokkary, R.H., Shreadah, M.A. and Abdel Hamid, O.G. (2017) CrossLinked Graphene Oxide Sheets via Modified Extracted Cellulose with High Metal Adsorption. Carbohydrate Polymer, 172, 20-27. https://doi.org/10.1016/j.carbpol.2017.05.004

[24] Zayed, E.M., Sokker, H.H., Albishri, H.M. and Farag, A.M. (2013) Potential Use of Novel Modified Fishbone for Anchoring Hazardous Metal Ions from Their Solutions. Ecological Engineering, 61, 390-393. https://doi.org/10.1016/j.ecoleng.2013.09.010

[25] Agwaramgbo, L., Lathan, N., Edwards, S. and Nunez, S. (2013) Assessing Lead Removal from Contaminated Water Using Solid Biomaterials: Charcoal, Coffee, Tea, Fishbone, and Caffeine. Journal of Environmental Protection, 4, 741-745. https://doi.org/10.4236/jep.2013.47085

[26] Agwaramgbo, L., Edwards, S., Patterson, T. and Broadway, R. (2014) Desorption of Lead Adsorbed from Contaminated Water by Fishbone and Charred Spinach/Grape. British Journal of Applied Science \& Technology, 4, 1566-1575. https://doi.org/10.9734/BJAST/2014/7398

[27] Agwaramgbo, L., Lloynikka, W. and Demley, T. (2015) Fish Bones Proving Their Worth in the De-Leadification of Contaminated Water. British Journal of Applied Science \& Technology, 5, 244-249. https://doi.org/10.9734/BJAST/2015/13316

[28] Mahmoud, M.E., Yakout, A.A., Abdel-Aal, H. and Osman, M.M. (2011) Enhanced Biosorptive Removal of Cadmium from Aqueous Solutions by Silicon Dioxide Nano-Powder, Heat Inactivated and Immobilized Aspergillus ustus. Desalination, 279, 291-297. https://doi.org/10.1016/j.desal.2011.06.023

[29] Kongsri, S., Janpradit, K., Buapa, K., Techawongstien, S. and Chanthai, S. (2013) Nanocrystalline Hydroxyapatite from Fish Scale Waste: Preparation, Characterization and Application for Selenium Adsorption in Aqueous Solution. Chemical Engineering Journal, 215-216, 522-532. https://doi.org/10.1016/j.cej.2012.11.054

[30] Zhang, J., Wanga, Q. and Wang, A. (2010) In Situ Generation of Sodium Alginate/Hydroxyapatite Nanocomposite Beads as Drug-Controlled Release Matrices. Acta Biomaterialia, 6, 445-454. https://doi.org/10.1016/j.actbio.2009.07.001

[31] Mobasherpour, I., Heshajin, M.S., Kazemzadeh, A. and Zakeri, M. (2007) Synthesis of Nanocrystalline Hydroxyapatite by Using Precipitation Method. Journal of Alloys and Compounds, 430, 330-333. https://doi.org/10.1016/j.jallcom.2006.05.018

[32] Mahmoud, M.E. and Al-Bishri, H.M. (2011) Supported Hydrophobic Ionic Liquid on Nano-Silica for Adsorption of Lead. Chemical Engineering Journal, 166, 157-167. https://doi.org/10.1016/j.cej.2010.10.046 
[33] Lima, H.K., Teng, T.T., Ibrahim, M.H., Ahmad, A. and Chee, H.T. (2012) Adsorption and Removal of Zinc(II) from Aqueous Solution Using Powdered Fish Bones. APCBEE Procedia, 1, 96-102. https://doi.org/10.1016/j.apcbee.2012.03.017

[34] Parhi, P., Ramanan, A. and Ray, A.R. (2006) Preparation and Characterization of Alginate and Hydroxyapatite-Based Biocomposite. Applied Polymer Science, 102, 5162-5165. https://doi.org/10.1002/app.24706

[35] Salah, T.A., Mohammad, A.M., Hassan, M.A. and El-Anadouli, B.E. (2014) Development of Nano-Hydroxyapatite/Chitosan Composite for Cadmium Ions Removal in Wastewater Treatment. Journal of the Taiwan Institute of Chemical Engineers, 45, 1571-1577. https://doi.org/10.1016/j.jtice.2013.10.008

[36] Jang, S.H., Min, B.G., Jeong, Y.G., Lyoo, W.S. and Lee, S.C. (2008) Removal of Lead Ions in Aqueous Solution by Hydroxyapatite/Polyurethane Composite Foams. Journal of Hazardous Materials, 152, 1285-1292.

https://doi.org/10.1016/j.jhazmat.2007.08.003

[37] Mahmoud, M.E. and Gohar, G.A. (2000) Silica Gel-Immobilized-Dithioacetal Derivatives as Potential Solid Phase Extractors for Mercury(II). Talanta, 51, 77-87. https://doi.org/10.1016/S0039-9140(99)00249-0

[38] Yin, H., He, B., Lu, X., Peng, H., Ye, J. and Yang, F. (2008) Improvement of Chromium Biosorption by $\mathrm{UV}-\mathrm{HNO}_{2}$ Cooperative Mutagenesis in Candida utilis. Water Research, 42, 3981-3989. https://doi.org/10.1016/j.watres.2008.07.005

[39] Shishehbore, M.R., Afkhami, A. and Bagheri, H. (2011) Salicylic Acid Functionalized Silica-Coated Magnetite Nanoparticles for Solid Phase Extraction and Preconcentration of Some Heavy Metal Ions from Various Real Samples. Chemistry Central Journal, 5, 1535-1545. https://doi.org/10.1186/1752-153X-5-41 